\title{
Targeted drug delivery and vaccinology approaches using virus-like particles for cancer
}

\author{
Șeyma Sereflioğlu', Emine Yapıcı' , S. Hande Tekarslan Șahin², Yıldız Özsoy², Cem Bülent Üstündağ1* \\ 'Department of Bioengineering, Yıldız Technical University, 34210, İstanbul, Turkey \\ 2Department of Pharmaceutical Technology, Faculty of Pharmacy, İstanbul University, 34116, İstanbul, Turkey
}

Cite this article as: Șereflioğlu Ș, Yapıcı E, Tekarslan Șahin ȘH, Özsoy Y, Üstündağ CB (2017). Targeted drug delivery and vaccinology approaches using virus-like particles for cancer. Istanbul J Pharm 47 (3): 112-119.

\begin{abstract}
Nanotechnology has the potential to make significant alterations in the treatment of diseases such as cancer through targeted drug delivery nanoparticles. Virus-like particles (VLPs) are composed of the capsid proteins that do not carry the viral genome and are also noninfectious. VLPs are self-assembling competent protein structures with identical or highly related structures to their corresponding native viruses. VLPs that have precise 3D nanostructures exhibit a notable diversity in shapes and structures. They can be produced in large quantities through biological amplification and growth. External protein inserts can be displayed through genetic methods or chemical modifications. Functionalized VLPs when used as delivery systems have the ability to target with specificity and can attract macrophages for the destruction of cancer cells. The capability to target tumors for the delivery of therapeutic agents is an important goal of the design approaches of VLPs. Against the current problems in cancer therapies, delivery systems using VLPs are an arising and promising field with the potential to exhibit solutions. Cancer therapies require specific targeting of the diagnostic element or the drug to tumor cells without binding to or affecting healthy cells and tissues. Specialization of the VLPs provides an opportunity for using them as site-specific drug delivery systems in cancer therapy while reducing the systemic toxicity and the overall damage to healthy cells. With fewer side effects, immunotherapy is also a promising alternative for cancer treatment by primarily activating the host's immune system. Cancer vaccines are aimed at inducing an immune response in the host, thereby generating a defensive mechanism against tumor cells. VLPs can be used as a vaccine without the requirement of any adjuvant due to their naturally optimized particle size and their repetitive structural order. Therefore, the aim of this review is to provide basic information about VLPs and describe previous research on VLPs used as drug and vaccine delivery systems and their applications in different types of cancer.
\end{abstract}

Keywords: Nanocarriers, virus-like particles, drug delivery, cancer vaccine, cancer therapy

\section{INTRODUCTION}

Virus-like particles (VLPS) are constituted of one or more viral proteins which are self-assembling particles expressed in vitro through recombinant technologies. The self-assembling feature of these proteins results in the generation of subviral or viral particles in the 20-100 nm size range, typically (Ghasparian et al. 2011). The high stability of VLPS, their symmetric spatial organization, ease of obtaining and purification, safety, and the possibility of directed modification make these nanoparticles ideal carriers of drugs, biologically active peptides and whole proteins (antigens, receptors, enzymes, etc.) (Blokhina et al. 2013).

Previously, VLPS have been produced for over thirty different infectious viruses in humans and animals. VLPS contain one or more structural proteins and they have features such as self-assembly. Morphological properties of VLPS are similar to native viruses. Due to being lack of infectious genetic material, VLPS are not amenable to replication and being infective, unlike native viruses. The general features of VLPs are summarized in Figure 1 as a scheme. In case of usage in vaccines, virus-like particles require no adjuvant as a safe vaccine candidate. To produce virus-like particles, different viruses offer different structures. For example, parvoviruses have viral capsids containing one or two major proteins are simple while viral capsids of picornaviruses are complex 


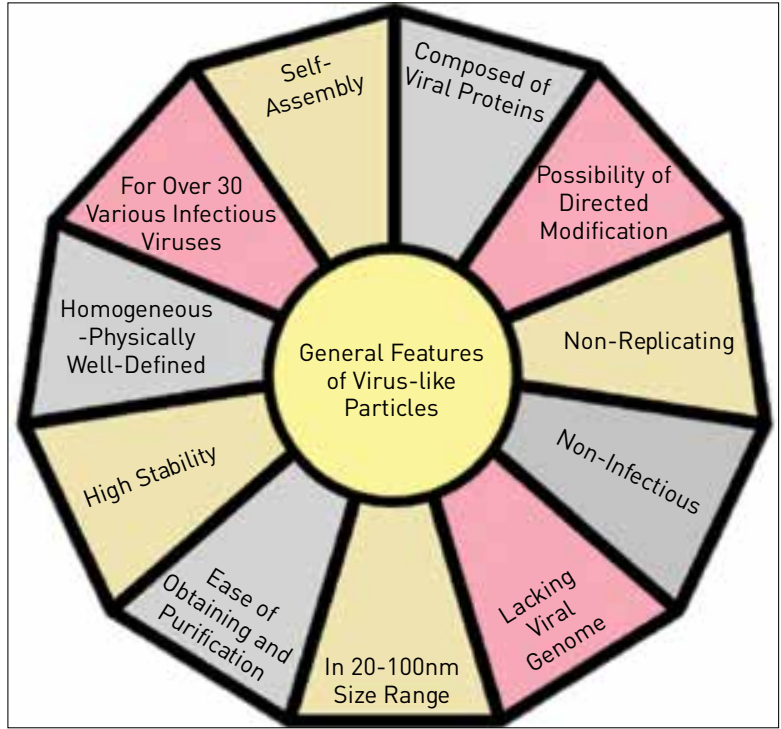

Figure 1. General features of virus-like particles as hollow nanocages

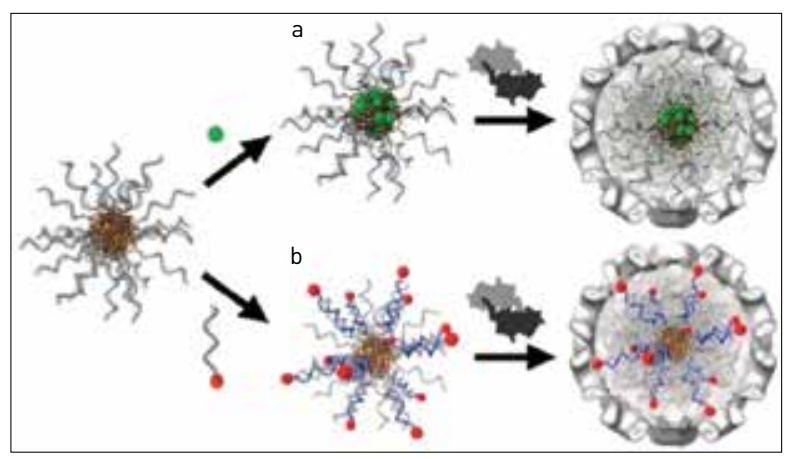

Figure 2.. DNA micelle-templated virus-like particle formations. Green shows hydrophobic molecules loaded into the core of the micelle in (a). Red shows hydrophilic molecules attached to complementary DNA strands by hybridization and equipping the micelles in (b) (Ma et al. 2012)

and these complex viral capsids showed diversity in protein layers which are encoded by many different mRNAs or viral capsid of picornaviruses is from a single polyprotein. Viral capsids of some viruses' such as influenza, HIV, and hepatitis $C$ are acquired from the host cell, and also viral glycoprotein spikes. They have lipid bilayer and lipid envelopes (Shirbaghaee and Bolhassani 2016).

VLPs have definite 3D nanostructures and they show a diversity of shapes and structures. By using biological amplification and growth, production of VLPs can be in great amounts. They can display external protein inserts through modifications/ techniques as genetically or chemically. The feature of being selective about the deposition of organic or inorganic materials, at specific locations on the VLP provides fine adjustment controlling of the assembly of nanomaterial, size and spacing that results in uniform and reproducible nanoarchitectures (Zhou et al. 2014).

Some VLPs have proved more immunogenic than recombinant protein immunogens vaccines, and are capable to induce both the humoral and cellular response of the immune system. VLPs structurally mimic their parent virus thus they could be used as a safe alternative for inactivated virus vaccines. Additionally, binding to pattern-recognition receptors and B-cell receptors of VLPS can induce direct immune system. Due to their naturally-optimized particle size and repetitive structural order, VLPS can be used as a vaccine without any adjuvant requirement. Immunogenicity of the VLPs also generates great potential to use them for immune therapy, targeted drug delivery, and gene therapy, aside from their applications in vaccination (Teunissen et al. 2013; Smith et al. 2015).

VLPs have biocompatible and monodisperse properties, also are capable of scale-up production and they are amenable to multiple functionalization strategies. These properties made VLPs advantageous to be used as delivery system. Beside chemical engineering, affinity tags or targeting peptides can be introduced by genetic engineering.As an example, Figure 2 represents DNA micelle templated VLP formation (Ma et al. 2012).

\section{Modifications of VLPs}

In some cases, VLPs could be modified chemically and genetically in order to gain extra functionalities. Drugs, epitopes, peptide fragments have been added to the surface of the particle by genetic engineering to use VLPs as nanocarriers. Disassembly and reassembly features of some VLPs provide a crucial way for encapsulation of drugs, peptide fragments, genome components. These unique characteristics give many advantages in comparison with synthetic nanoparticles (Yildiz et al. 2011).

Both the outer and inner surfaces of the VLPS can be functionalized by modification of the protein subunits genetically or chemically. Such modifications can cause considerable changes in the physicochemical properties and offer novel functions for VLPs (Smith et al. 2015). VLPs'inner surface can be modified to increase the loading efficiency and new affinity properties are acquired for a specific size of the foreign molecules. Shen et al. (2015) have demonstrated a method for encapsulation of magnetic nanoparticles into VLPs by hypothesizing a mutant HBC144 VLPs, which is produced by interpolation of six histidine residues (Histag) at the N-terminal ends and showed at the inner surface of the VLPs. It depends on the affinity of histidine tags to metal-ion complexes, such as nickel-nitrilotriacetic acid (nickel-NTA) chelate. By this method, the magnetic core containing VLPs were obtained at high efficiency with the properties of uniformly sized and monodispersed and the cellular uptake ability of $\mathrm{Fe}_{3} \mathrm{O}_{4}-\mathrm{NTA}^{-\mathrm{Ni}^{2+}}$ core-containing $\mathrm{HBc}$-144$\mathrm{His}$ VLPS was higher than pure $\mathrm{Fe}_{3} \mathrm{O}_{4}$ nanoparticles. Core size strong affects the efficiency of the VLPs encapsulation and correlation between the T-number (Triangulation number, facets per triangular face of an icosahedron) and the self-assembly efficiency could be the reason of this effect. It is concluded that $20 \mathrm{~nm}$ is the maximum size limit for VLP formation because VLP formation with large cores are failed. In case of exceeding this limit, it prevents obtaining stable particles. As a crucial result of this study, these core-containing VLPs have been shown to be very effective cellular T2 contrast agents for MRI applications (Shen et al. 2015). 


\section{Cancer Drug Delivery with VLPs}

Virus-like nanoparticles are promising technologies as a new delivery platform. Their various features render them a convenient and potential candidate for targeted delivery of nucleic acids, peptide fragments, and therapeutic drugs within the protein structure. They have hollow structures which are composed of self-assembling protein subunits and considered as protein cages. Protein nanocages are often produced in living hosts. To precisely control over particle stability, drug encapsulation, surface charge and ligand display, functional elements can be applied as internal, external, and inter-subunit by per-

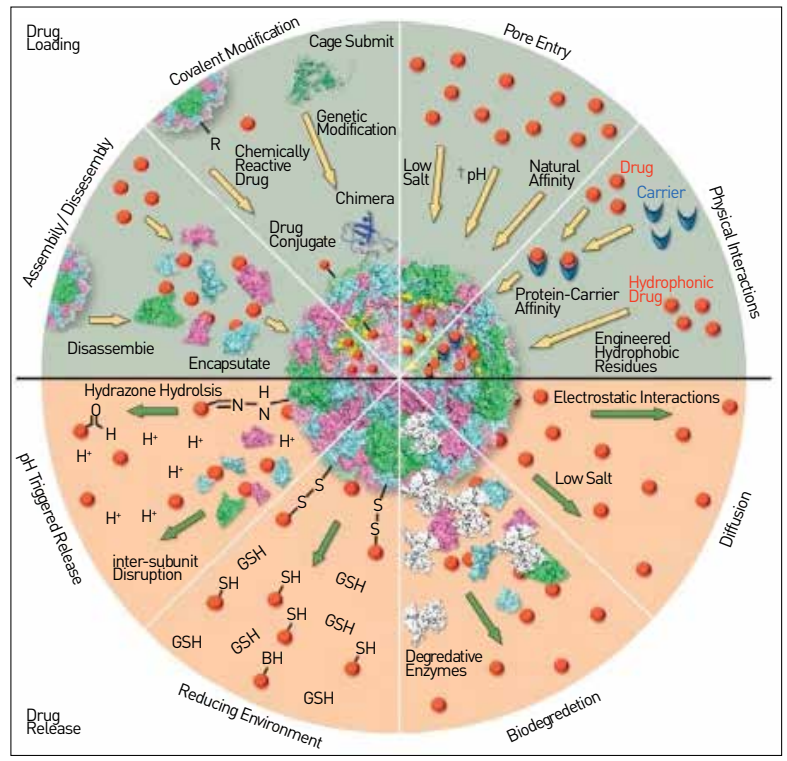

Figure 3. Methods that were used for drug loading (upper panel) and methods that were used for drug release (lower panel) in VLPs. R: any reactive amino acid side chain; GSH: glutathione. Cowpea chlorotic mottle virus is used as the representative scaffold. (Molino and Wang 2014) forming protein engineering techniques (Molino and Wang 2014).

Some VLPS are more capable in case of using as a nanocarrier. For example, Bacteriophage MS2 VLPs possess many properties as a delivery platform. These particles can be obtained in a very easy way by the recombinant-protein technology. On the other hand, the MS2 capsid sympathizes with the pac site of DNA or RNA and can encapsulate the target RNA or DNA by locating at the five terminus of the pac site. This inhibits degradation risks of the target RNA or DNA by nucleases. Antigenic components, epitopes can be delivered by designed MS2 VLPS for clinical approach MS2CP gene has a specific site to insert DNA oligonucleotide and the epitope peptide can be presented to the immune system after the expression. In addition, VLPs can display viral antigens on their surface of the capsid, and stimulate a higher immunologic response. Major advantages of MS2 VLPs are their great stability and appropriate size for presenting of viral antigenic epitopes. Moreover, MS2 VLPS can also be used as potential nanocarriers for targeted and passive drug delivery. Drugs can be packaged to MS2CP, MS2 during the self-assembly step (Fua and Li 2016).

The present strategies for a particulate system are defined by dynamics, the type of drug that is loaded, its structure and the environment that the nanoparticle is targeted. The strategies are described in Figure 3 (Molino and Wang 2014).

In cancer treatment, tumour-targeted drug delivery is an attractive strategy. The various VLPs delivery systems which are investigated before in treatment of cancer were shown in Table 1. For different types of cancer drugs, different VLPs systems were developed such as MS2 bacteriophage to deliver 5- fluorouracil and doxorubicin; and murine polyomavirus for methotrexate. (Ashley et al., 2011; Abbing et al., 2004) To deliver Paclitaxel, a JC polyomavirus VLP system was also synthesized which encapsulates the coupled drug with cyclo-

Table 1. Summary of various VLPs, which have been investigated as delivery platforms for cancer therapeutics

\begin{tabular}{|c|c|c|c|}
\hline Drug & Virus-Like Particle & Target of Drug & References \\
\hline Paclitaxel & Adenovirus JC polyomavirus & $\begin{array}{c}\text { AIDS-related Kaposi sarcoma, breast cancer, } \\
\text { and ovarian cancer }\end{array}$ & $\begin{array}{l}\text { Shan et al. } 2012 \\
\text { Niikura et al. } 2013\end{array}$ \\
\hline Bleomycin & Adenovirus & $\begin{array}{l}\text { Lymphoma, penile cancer, squamous cell carcinoma } \\
\text { of the cervix, head-neck, and vulva, testicular cancer }\end{array}$ & Zochowska et al. 2009 \\
\hline 5- Fluorouracil & $\begin{array}{l}\text { I MS2 bacteriophage Avian } \\
\text { sarcoma leukosis virus }\end{array}$ & $\begin{array}{l}\text { Some skin cancers, head and neck cancers, breast } \\
\text { cancer, stomach cancer, anal cancer, colon cancer }\end{array}$ & $\begin{array}{c}\text { Ashley et al. } 2011 \\
\text { Kaczmarczyk et al. } 2011\end{array}$ \\
\hline Doxorubicin & $\begin{array}{l}\text { Cowpea mosaic virus } \\
\text { Cucumber mosaic virus } \\
\text { Hibiscus ringspot virus } \\
\text { MS2 bacteriophage } \\
\text { Red clover necrotic } \\
\text { mosaic virus }\end{array}$ & $\begin{array}{c}\text { Leukemia, lymphoma, neuroblastoma, sarcoma, } \\
\text { Wilms tumour, and cancers of the breast, lung, } \\
\text { thyroid, stomach, ovary, and bladder }\end{array}$ & $\begin{array}{l}\text { Aljabali et al. } 2013 \\
\text { Zeng et al. } 2013 \\
\text { Ren et al. } 2007 \\
\text { Ashley et al. } 2011 \\
\text { Lockney et al. } 2011\end{array}$ \\
\hline SiRNA & $\begin{array}{l}\text { Hepatit B virus } \\
\text { JC polyomavirus } \\
\text { MS2 bacteriophage }\end{array}$ & $\begin{array}{l}\text { By disease-related gene suppression- specifically } \\
\text { inhibit oncogene overexpression or gene mutation }\end{array}$ & $\begin{array}{c}\text { Choi et al. } 2013 \\
\text { Chou et al. } 2010 \\
\text { Galaway\&Stockley } 2013\end{array}$ \\
\hline Methotrexate & Murine polyomavirus & $\begin{array}{c}\text { Certain types of cancer of the lung, breast, } \\
\text { head-neck, or skin }\end{array}$ & Abbing et al. 2004 \\
\hline
\end{tabular}


dextrins as hydrophobic pockets through disulfide bonds inside the VLPS and has capable of glutathione (GSH)- triggered release of drug molecules. (Niikura et al., 2013). In a previous study, Shan et al. explained that modified adenovirus can be strongly targeted to tumour and has less toxicity effect to normal tissues. In a further study, commonly used clinical anticancer drug, Paclitaxel was conjugated to folate-modified adenovirus nanoparticles by using linkers to form two prodrugs. The results showed that the targeting and residence time of Paclitaxel can be improved by Paclitaxel-conjugated vector in tumour site. In vitro and in vivo studies show that Coxsackie adenovirus receptor or foliate receptor-mediated uptake of Paclitaxel induced highly anti-tumour activity. The results showed that chemically modified adenovirus vector has the potential to be used as a drug-loaded tumour-targeting delivery system (Shan et al. 2012). In chemotherapeutic approaches, inactive prodrugs together with enzymes have been widely used. These combinations convert the prodrugs to an active form. In another study, 5-Fluorocytosine has been introduced as a prodrug. Fcy protein converts 5-fluorocytosine into a highly cytotoxic compound mostly used in cancer chemotherapy, which is 5-fluorouracil. Then, Fur protein converts 5-FU to 5-F UMP, which blocks DNA synthesis. Yet this approach depends on expression of the enzymes required to convert the prodrug into the cytotoxic component. This problem was tried to solve by generating VLPS that composed of Gag-Fcy-Fur fusion for the delivery of enzymes that could be used for prodrug-to-active drug conversion (Kaczmarczyk et al. 2011).

Bleomycin is an anticancer antibiotic and has systemic toxicity and dose-dependent pneumonitis able to progress to lung fibrosis although its usage for wide range of cancer types such as lymphoma, penile cancer and testicular cancer. To enhance bleomycin delivery, adenovirus VLP vector was used by Zochowska et al. (Zochowska et al. 2009). Doxorubicin, which damages DNA and may kill cancer cells and cure many types of cancer such as lymphoma, leukemia and breast cancer, was encapsulated into different VLPs types (Aljabali et al. 2013; Ren et al. 2007; Ashley et al. 2011; Lockney et al. 2011). For example, encapsulated doxorubicin into cucumber mosaic virus was targeted to folate-expressing cancer cells in vivo. The results showed that cardiotoxicity was reduced and antitumour responses were increased, compared to free drug (Zeng et al. 2013).

Another treatment method for cancer is to silence gene expression by RNA interference (RNAi) however delivering sequences of RNAi in vivo remains a problem. To overcome this problem JC virus VLPs has been used as a vector for delivering RNAi in silencing the cytokine gene of $\mathrm{IL}-10$ which resulted in reducing $\mathrm{IL}-10$ expression by 85 to $89 \%$, when compared with VLPS alone. (Chou et al. 2010) Galaway\&Stockley also showed that VLPs reassembled in vitro with the RNA bacteriophage MS2 coat protein and an RNA conjugate encompassing a siRNA and a known capsid assembly signal can be targeted to HeLa cells by protecting from nuclease. (Galaway\&Stockley, 2013).

\section{Nanovaccinology with VLPs against Cancer}

The use of nanotechnology in vaccinology, in particular, has been increasing exponentially in the past decade, leading to the birth of "nanovaccinology". In therapeutic approaches, nanoparticles are used as either a delivery system to improve antigen processing or as an immunostimulant adjuvant to activate or increase immunity. Therapeutic nanovaccinology is mostly applied for cancer treatment and is increasingly explored to treat other diseases or conditions, such as Alzheimer's, hypertension, and nicotine addiction (Zhao et al. 2014). The self-assembly of the viral particle needs a single viral capsid protein To make VLP vaccines. Mostly, production of VLPS are based on insect and yeast cell-based systems due to their advantageous for commercial vaccine manufacturing, ease of production and ability to produce complex viral protein targets (Rosenthal et al. 2014). Moreover, VLP vaccines do not need a chemical treatment step for inactivation which could affect the structure of the antigen epitopes of the surface glycoproteins conformationally (Matassov et al. 2007).

Several viruses are linked to cancer in humans. In the year 2002, 1.9 million cases that represent $17.8 \%$ of the global cancer casesare estimated as cancer associated with viral infections (Parkin 2006). Viruses can play roles at different stages of the cancer development, and the association of a virus with a given cancer can occur anywhere from 15 to 100\%. It is thought that 15 and $20 \%$ of all human cancers may have a viral cause (Parkin 2006; zur Hausen 2001). Preventing cancer via vaccination became very popular starting in the late 1980s. Human vaccines against human papillomavirus, hepatitis E virus and hepatitis B virus use recombinant virus-like particles as the antigen (Zhao et al. 2013). Recombinant hepatitis B virus has licensed VLP vaccines. The first two of these vaccines are Recombivax and Engerix-B and they are both $\mathrm{HBV}$ recombinant DNA vaccines. They consist of purified non-infectious subunits of the HBV surface antigen (i.e., HBsAg) (Lacson et al. 2005). After the invention of Recombivax-HB (Merck\&Co.) and Engerix-B (GlaxoSmithKline, GSK), Human Papillomavirus (HPV) vaccines are produced by the same approach. Gardasil (Merck \& Co.; produced in yeast) and Cervarix (GSK; produced in insect cells) are examples of Human Papillomavirus vaccines which were produced in the late 2000s (Dillner et al. 2010; Lehtinen et al. 2012; Kaufmann et al. 2010; Kreimer et al. 2011). Both the HBV and HPV vaccines containrecombinant virus-like particles (Glaxosmithkline Vaccine HPVSG et al. 2009; Mao et al. 2006). Clinical trials of these vaccines showed that they prevent infection by inducing protective and neutralizing antibodies (Schiller et al. 2012). Recombinant HBsAg is produced in yeast by cloning of a part of the HBV DNA into the yeast Saccharomyces cerevisiae (Hauser et al. 1987). The same antibodies to HBsAg are induced to be produced by Recombivax and Engerix-B and both vaccines have similar immunogenic properties (West and Calandra 1996). More immunogenic VLP vaccines containing Pre-S1, Pre-S2 and hepatitis B surface antigens have been developed. The third generation hepatitis B vaccine, which can produce a strong antibody response, is Bio-Hep B (Alpar et al. 2014). Production of Bio-Hep B is in mammalian Chinese hamster ovary $(\mathrm{CHO})$ cells and contains Pre-S1 (large), Pre-S2 (middle) and the small (s) surface proteins of HBV (Hourvitz et 
Table 2. VLP vaccines with license (modified from Kushnir et al. 2012)

\begin{tabular}{|c|c|c|c|}
\hline Vaccine Name & Disease & Company & Expression System \\
\hline Epaxal & Hepatitis A & Crucell & Cell-free \\
\hline GenHevac B & Hepatitis B & Pasteur-Merieux Aventis & Mammalian ( $\mathrm{CHO}$ cells) \\
\hline Bio-Hep-B & Hepatitis B & BTG (SciGen, FDS Pharma) & Mammalian ( $\mathrm{CHO}$ cells) \\
\hline DTP-Hep B & Hepatitis B & P.T. Bio Farma & Yeast (P. pastoris) \\
\hline Engerix B & Hepatitis B & GSK & Yeast (S. cerevisiae) \\
\hline Enivac HB & Hepatitis B & Panacea Biotec & Yeast (P. pastoris) \\
\hline Euvax B & Hepatitis B & LG Life Sciences & Yeast (S. cerevisiae) \\
\hline Gene Vac B & Hepatitis B & Serum Inst. of India & Yeast (H. polymorpha) \\
\hline Heberbiovac HB & Hepatitis B & CIGB-Heber Biotec & Yeast (P. pastoris) \\
\hline Hepavax-Gene & Hepatitis B & Crucell & Yeast (H. polymorpha) \\
\hline Recombivax HB & Hepatitis B & Merck & Yeast (S. cerevisiae) \\
\hline Revac-B & Hepatitis B & Bharat Biotech International & Yeast (P.pastoris) \\
\hline Shanvac-B & Hepatitis B & Shanta Biotechnics & Yeast (P.pastoris) \\
\hline Gardasil & HPV & Merck & Yeast (S. cerevisiae) \\
\hline Cervarix & HPV & GSK & Insect (High FiveTM cells) \\
\hline Inflexal V & Influenza & Crucell & Cell-free \\
\hline HeberNasvac & Hepatitis B & The Cuban regulatory authorities & E.coli \\
\hline Hecolin & Hepatitis B & Xiamen Innovax Biotech & E.coli \\
\hline
\end{tabular}

al. 1996). Yeast (Venters et al. 2004), insects, bacteria Escherichia coli (Wei et al. 2014; Li et al. 2015), plant (Kapusta et al. 1999) and mammalian cells were used for the production of the approved VLP-based vaccines (Table 2). Several recombinant protein-based products were derived from E.coli such as the first recombinant human insulin (Kyriakopoulos et al. 2013). There are over 50 VLP based vaccines which are produced in different expression hosts between 1986 and 2015 (Huang et al. 2017). Hecolin and Heber Nasvac are produced in E.coli and are licensed VLP-based vaccines (Lua et al. 2014; Huang et al. 2017). Hecolin is the first commercialized E.coli derived hepatitis E vaccine (Proffitt, 2012). ABX203 (trade name HeberNasvac) is a VLP vaccine for hepatitis B treatment and is the first marketing authorized vaccine by the Cuban regulatory authorities in 2015 (Lobaina et al. 2015; http://www.abivax.com/images/ pdf/151208_ABX203_Cuban_Authorization.).

For vaccinology in cancer, Human Papilloma Virus (HPV) VLPS in GARDASIL vaccine is a good example. It prevents HPV infections which can be cause of cervical cancer and warts. The major capsid protein L1 of HPV are expressed into VLPs either in yeast or Baculovirus systems. It mimicks the original epitopes of virions and shows protective immune responses when properly adjuvanted. The adsorbed VLPs of each HPV type is prepared and combined to produce GARDASIL, an aluminumcontaining adjuvant is used for adsorbtion of all of the VLPS. The VLP morphology is checked to figure out whethertheinteraction with the aluminum adjuvant surface modifies the VLP morphology. According to results, adsorption onto adjuvants did not affect the morphology (Zhao et al. 2014).
Goldinger et al. (2010) have designed an anticancer vaccine MelQbG10 virus-like nanoparticle loaded with CpG-oligonucleotides and coupled to a peptide derived from Melan-A. This vaccine may trigger cytotoxic $T$ lymphocyte response of the immune system against Melan A expressed melanoma cancer cells. As a result, vaccination of patients at phase II clinical trial resulted in an increase of T-cells at the injection site. The biopsies of the injection site demonstrated an enhanced expression of CD4 and CD8 which confirms the flow of T-cells. Furthermore, in case of evaluation of Melan A expression, it exhibited a down-regulation in the tumour tissue after vaccination. (Goldinger et al. 2010).

\section{Chimeric Virus-Like Particles and Cancer}

The lacking genomic material of VLPs provides great safety profile to use in numerous fields, such as vaccines, drug delivery, in vitro imaging systems (Grgacic and Anderson, 2006). On the other hand, chimeric VLPS, occurring from two distinct capsid proteins, are the specific approach for both of vaccination and drug delivery system at the same time. As an example, gag and M1 are two capsid proteins from influenza virus and Deo and his colleagues used these two capsid proteins to express colon carcinoma cell-targeting chimeric virus-like particles. These chimeric VLPS displayed a variable fragment region targeting colon carcinoma cells. chimeric VLPs were packaged by Large unilamellar vesicles containing calcein-AM or doxorubicin. The dye and the drug were delivered to the cells by VLPS successfully and targeted cancer cells with high specificity (Deo et al. 2015). 
Choi et al. also used chimeric VLPs and demonstrated how a chimeric VLP can be used in gene silencing. Previously, lentiviral vectors were the effective vectors in gene silencing for a long period in mice. However, the usage of these vectors have some risks due to mutagenesis and carcinogenesis which may occur during the integration of their DNA into the host's genomic DNA. This limits their use for clinical applications. So in this study, chimeric siRNA/capsid nanocarrier complexes were produced. In the cell culture system, these nanocarriers suppressed RFP gene expression efficiently. As a result, they proved tumor-specific targeting ability of the chimeric nanocarrier in vivo. Moreover, the siRNAs in capsid shell are protected against nucleases in plasma by encapsulation, so the enhanced stability of siRNA during body circulation was also proved. Due to overexpression of the RGD-mediated binding to integrin receptors on tumour cells, delivery of siRNA is accomplished to the tumour tissues in vivo efficiently by the multivalent RGD peptides on shell surface (Choi et al. 2013).

\section{Conclusion}

In recent years, studies were shown that VLPs are excellent candidates for vaccination and targeted drug delivery systems owing to their inherent properties; multimeric antigens, particulate structure, not being infectious. Here, we summarize some of them in vaccinology and drug delivery areas. The assembly, disassembly/reassembly, self-assembly features of the VLPs are known as a key point to design with modifications and encapsulation in order to provide extra immunogenic and functional properties. All these properties have made possible different mechanisms of drug encapsulation and specific targeting (Molino and Wang 2014).

Major advantages of VLPs are being appropriate for the induction of safe and efficient humoral and cellular immune responses. Thus, they can utilize in vivo applications without any toxicity and inflammatory response. Chemically and genetically modifications of VLPs make them more useful for specific applications than native forms. Recently, especially when targeted to a therapeutic site, the success of drugs inside a VLP system can be better than free drug while reducing side effects.

Recombinant VLP systems can be arranged to gain more functionalities to present drugs, imaging reagents, antigenic epitopes of a corresponding virus or another disease-associated antigen and specific targeting peptides to the internal and external surfaces of the particle. It supplies an important additional advantage because in the future, vaccinology should be able to produce vaccines which have both preventive and therapeutic effects. It is considered that by the use of VLP-based delivery systems, enhanced immunogenicity could be achieved.

Traditionally, against solid tumours only chemotherapy or accompanied radiotherapy is applied. However, traditional treatments which have lack of specificity for each cancer types results in side effects. In further doses of chemotherapy, tumour cells can become drug resistance and normal cells affected by toxins. In cases that require more dose intake, toxicity limits the chemotherapy-based treatment. Even just self-assembly and encapsulation features, the VLPs can be loaded according to the conditions required by the treatment. This distinctive flexibility provides many advantages over synthetic nanoparticles and consequently traditional treatments.

We hope that immunotherapy and preventative cancer vaccines control cancer in humans with fewer side effects than chemotherapy-based methods. Although all novel approaches, there are some drawbacks to overcome related with production processes, or with the formation of chimeric VLPS. Currently, the absence of reliable preclinical animal models and issues such as cost obstructs rapid and effective vaccine development. Also, further researches are required to understand behavioral features of VLP systems in vivo and to carry this technology from the laboratory to the clinic. However, with further studies, VLP-based technologies will continue to progress due to their predominant and great advantages and will be more applicable in future.

\section{REFERENCES}

- Abbing A, Blaschke UK, Grein S, Kretschmar M, Stark CM, Thies MJ, Walter J, Weigand M, Woith DC, Hess J, et al. (2004). Efficient intracellular delivery of a protein and a low molecular weight substance via recombinant polyo mavirus-like particles, J Biol Chem 279: 27410-27421. [CrossRef]

- $\quad$ Aljabali AA, Shukla S, Lomonossoff GP, Steinmetz NF, Evans DJ (2013). CPMV-DOX delivers. Mol Pharm 10: 3-10. [CrossRef]

- Alpar HO, Özsoy Y, Cevher E (2014). Nanotaşıyıcıların Aşı Uygulamasında Kullanılması. In: Zırh-Gürsoy A (ed.) Nanofarmasötikler ve Uygulamaları, Kontrollü Salım Sistemler Derneği, İstanbul, pp. 277-286.

- Ashley CE, Carnes EC, Phillips GK, Durfee PN, Buley MD, Lino CA, Padilla DP, Phillips B, Carter MB, Willman CL et al. (2011). Cell-specific delivery of diverse cargos by bacteriophage MS2 virus-like particles. ACS Nano 5: 5729-5745. [CrossRef]

- Blokhina EA, Kupriyanov W, Ravin NV, Skryabin KG (2013). The Method of Noncovalent in vitro Binding of Target Proteins to Virus-Like Nanoparticles Formed by Core Antigen of Hepatitis B Virus. Dokl Akad Nauk 448: 719-721. [CrossRef]

- Choi KM, Kim K, Kwon IC, Kim IS, Ahn HJ (2013). Systemic delivery of siRNA by chimeric capsid protein: tumor targeting and RNAi activity in vivo. Mol Pharm 10: 18-25. [CrossRef]

- Chou MI, Hsieh YF, Wang M, Chang JT, Chang D, Zouali M, Tsay GJ (2010). In vitro and in vivo targeted delivery of IL-10 interfering RNA by JC virus-like particles. J Biomed Sci 17: 51. [CrossRef]

- Dillner J, Kjaer SK, Wheeler CM, Sigurdsson K, Iversen OE, Hernandez-Avila M, Perez G, Brown DR, Koutsky LA, Tay EH, García P, Ault KA, Garland SM, Leodolter S, Olsson SE, Tang GW, Ferris DG, Paavonen J, Lehtinen M, Steben M, Bosch FX, Joura EA, Majewski S, Muñoz N, Myers ER, Villa LL, Taddeo FJ, Roberts C, Tadesse A, Bryan JT, Maansson R, Lu S, Vuocolo S, Hesley TM, Barr E, Haupt R. (2010). Four year efficacy of prophylactic human papillomavirus quadrivalent vaccine against low grade cervical, vulvar, and vaginal intraepithelial neoplasia and anogenital warts: randomised controlled trial. BMJ 341: c3493. [CrossRef]

- Deo VK, Kato T, Park EY (2015). Chimeric Virus-Like Particles Made Using GAG and M1 Capsid Proteins Providing Dual Drug Delivery and Vaccination Platform. Mol Pharm 12: 839-845. [CrossRef]

- Fua Y, Li J (2016). A novel delivery platform based on Bacteriophage MS2 virus-like particles. Virus Res 211: 9-16. [CrossRef] Galaway FA, Stockley PG (2013). MS2 viruslike particles: a robust, semisynthetic targeted drug delivery platform. Mol Pharm 10: 5968. [CrossRef] 
- Glaxosmithkline Vaccine HPVSG, Romanowski B, De Borba PC, Naud PS, Roteli-Martins CM, De Carvalho NS, Teixeira JC, Aoki F, Ramjattan B, Shier RM, Somani R, Barbier S, Blatter MM, Chambers C, Ferris D, Gall SA, Guerra FA, Harper DM, Hedrick JA, Henry DC, Korn AP, Kroll R,Moscicki AB, Rosenfeld WD, Sullivan BJ, Thoming CS, Tyring SK, Wheeler CM, Dubin G, Schuind A, Zahaf T, Greenacre M, Sgriobhadair A (2009). Sustained efficacy and immunogenicity of the human papillomavirus (HPV)-16/18 AS04adjuvanted vaccine: analysis of a randomised placebo-controlled trial up to 6.4 years. Lancet 374: 1975-1985. [CrossRef]

- Ghasparian A, Riedel T, Koomullil J, Moehle K, Gorba C, Svergun DI, Perriman AW, Mann S, Tamborrini M, Pluschke G, Robinson JA (2011). Engineered Synthetic Virus-Like Particles and Their Use in Vaccine Delivery. Chem Bio Chem 12: 100-109. [CrossRef]

- Goldinger SM, Imhof L, Willers J, French LE, Dummer R, (2010). Phase II clinical trial using Virus-Like Particle (VLP) vaccine including a melan-A analogon and imiquimod". Melanoma Res 20: e56. [CrossRef]

- $\quad$ Grgacic EV, Anderson DA (2006). Virus-like particles: Passport to immune recognition. Methods 40: 60- 65. [CrossRef]

- Hauser P, Voet P, Simoen E (1987). Immunological properties of recombinant HbsAg produced in yeast. Postgrad Med J 63: 83-91.

- Hourvitz A1, Mosseri R, Solomon A, Yehezkelli Y, Atsmon J, Danon YL, Koren R, Shouval D (1996). Reactogenicity and immunogenicity of a new recombinant hepatitis $B$ vaccine containing Pre S antigens: a preliminary report. J Viral Hepat 3: 37-42. [CrossRef]

- Huang X, Wang X, Jun Zhang J, Xia N, Zhao Q (2017). Escherichia coli-derived virus-like particles in vaccine development. Vaccines doi:10.1038/s41541-017-0006-8. [CrossRef]

- Kaczmarczyk SJ, Sitaraman K, Young HA, Hughes SH, Chatterjee DK (2011). Protein delivery using engineered virus-like particles. Proc Natl Acad Sci 108: 16998-17003. [CrossRef]

- Kapusta J, Modelska A, Figlerowicz M, Pniewski T, Letellier M, Lisowa O, Yusibov V, Koprowski H, Plucienniczak A, Legocki AB. (1999). A plant-derived edible vaccine against hepatitis B virus. FASEB J 13: 1796-9. [CrossRef]

- Kaufmann AM, Nitschmann S (2010). Vaccine against human papillomavirus: PATRICIA Study (PApilloma TRlal against Cancer In young Adults). Der Internist 51: 412-413. [CrossRef]

- Kreimer AR, Gonzalez P, Katki HA, Porras C, Schiffman M, Rodriguez AC, Solomon D, Jiménez S, Schiller JT, Lowy DR, van Doorn LJ, Struijk L, Quint W, Chen S, Wacholder S, Hildesheim A, Herrero R; CVT Vaccine Group (2011). Efficacy of a bivalent HPV 16/18 vaccine against anal HPV 16/18 infection among young women: a nested analysis within the Costa Rica Vaccine Trial. The lancet oncology 12: 862-870. [CrossRef]

- Kyriakopoulos S, Kontoravdi C (2013). Analysis of the landscape of biologicallyderived pharmaceuticals in Europe: dominant production systems, molecule types on the rise and approval trends. Eur J Pharm Sci 48: 428-441. [CrossRef]

- Kushnir N, Streatfield SJ, Yusibov V (2012). Virus-like particles as a highly efficient vaccine platform: diversity of targets and production systems and advances in clinical development. Vaccine $\mathbf{3 1}$ : 58-83. [CrossRef]

- Lacson E, Teng M, Ong J, Vienneau L, Ofsthun N, Lazarus JM (2005). Antibody response to Engerix-B and Recombivax-HB hepatitis $B$ vaccination in end-stage renal disease. Hemodial Int 9: 367-75. [CrossRef]

- Lehtinen M, Paavonen J, Wheeler CM, Jaisamrarn U, Garland SM, Castellsagué X, Skinner SR, Apter D, Naud P, Salmerón J, Chow SN, Kitchener H, Teixeira JC, Hedrick J, Limson G, Szarewski A, Romanowski B, Aoki FY, Schwarz TF, Poppe WA, De Carvalho NS, Germar MJ, Peters K, Mindel A, De Sutter P, Bosch FX, David MP, Descamps D, Struyf F, Dubin G; HPV PATRICIA Study Group. (2012).
Overall efficacy of HPV-16/18 AS04-adjuvanted vaccine against grade 3 or greater cervical intraepithelial neoplasia: 4-year endof-study analysis of the randomised, double-blind PATRICIA trial. The lancet oncology 13: 89-99. [CrossRef]

Li SW, Zhao Q, Wu T, Chen S, Zhang J, Xia NS (2015). The development of a recombinant hepatitis E vaccine HEV 239. Hum Vaccin Immunother 11: 908-914. [CrossRef]

- Lobaina Y, Aguiar J, Pentón E, Aguilar JC (2015). Demonstration of safety, immunogenicity and evidences of efficacy of the therapeutic vaccine candidate HeberNasvac and characterization of chronic hepatitis B patient populations. Biotecnología Aplicada 32: $3511-3513$.

- $\quad$ Lockney DM, Guenther RN, Loo L, Overton W, Antonelli R, Clark J, Hu M, Luft C, Lommel SA, Franzen S (2011). The Red clover necrotic mosaic virus capsid as a multifunctional cell targeting plant viral nanoparticle, Bioconjug Chem 22: 67-73. [CrossRef]

- Lua LH, Connors NK, Sainsbury F, Chuan YP, Wibowo N, Middelberg AP (2014). Bioengineering virus-like particles as vaccines. Biotechnol Bioeng 111: 425-440. [CrossRef]

- Ma Y et al. (2012). Virus-based nanocarriers for drug delivery. Adv Drug Deliv Rev 64: 811-825. [CrossRef]

Mao C, Koutsky LA, Ault KA, Wheeler CM, Brown DR, Wiley DJ, Alvarez FB, Bautista OM, Jansen KU, Barr E. (2006) Efficacy of human papillomavirus-16 vaccine to prevent cervical intraepithelial neoplasia: a randomized controlled trial. Obstetrics and Gynecology 107: 18-27. [CrossRef]

Matassov D, Cupo A, Galarza JM, (2007). A Novel Intranasal VirusLike Particle (VLP) Vaccine Designed to Protect against the Pandemic 1918 Influenza A Virus (H1N1). Viral Immunol 20: 441-52. [CrossRef]

- Molino NM, Wang S (2014). Caged protein nanoparticles for drug delivery. Curr Opi Biotechno/ 28: 75-82. [CrossRef]

Niikura K, Sugimura N, Musashi Y, Mikuni S, Matsuo Y, Kobayashi S, Nagakawa K, Takahara S, Takeuchi C, Sawa H et al. (2013). Virus-like particles with removable cyclodextrins enable glutathionetriggered drug release in cells. Mol Biosyst 9: 501-507. [CrossRef]

- $\quad$ Parkin DM (2006). The global health burden of infection-associated cancers in the year 2002. Int J Cancer 118: 3030-3044. [CrossRef]

Proffitt A (2012). First HEV vaccine approved. Nature Biotechnology doi:10.1038/nbt0412-300a. [CrossRef]

- $\quad$ Ren Y, Wong SM, Lim LY (2007). Folic acid-conjugated protein cages of a plant virus: a novel delivery platform for doxorubicin, Bioconjug Chem 18: 836-843. [CrossRef]

- $\quad$ Rosenthal et al. (2014). Pathogen-like particle vaccines: biomimetic vaccine carriers engineered at the nanoscale. Curr Opi Biotechnol 28: 51-58. [CrossRef]

Schiller JT, Castellsague X, Garland SM (2012). A review of clinical trials of human papillomavirus prophylactic vaccines. Vaccine $\mathbf{3 0}$ F123-F138. [CrossRef]

- $\quad$ Shan L, Cui S, Du C, Wan S, Qian Z, Achilefu S, Gu Y (2012). A paclitaxel- conjugated adenovirus vector for targeted drug delivery for tumor therapy. Biomater 33: 146-162. [CrossRef]

Shen L, Zhou J, Wang Y, Kang N, Ke X, Bi S, Ren L (2015). Efficient Encapsulation of $\mathrm{Fe}_{3} \mathrm{O}_{4}$ Nanoparticles into Genetically Engineered Hepatitis B Core Virus-Like Particles Through a Specific Interaction for Potential Bioapplications, Small Journal, Wiley-VCH $\mathrm{GmbH} \& \mathrm{Co}$.

- Shirbaghaee Z, Bolhassani A, (2016). Different Applications of Virus-Like Particles in Biology and Medicine: Vaccination and Delivery Systems. Biopolym 105: 113-132. [CrossRef]

Smith JD, Morton LD, Ulery BD, (2015). Nanoparticles as synthetic vaccines. Curr Opin Biotechno/ 34: 217-224. [CrossRef] 
- Teunissen EA, Raad M, Mastrobattista E (2013). Production and biomedical applications of virus-like particles derived from polyomaviruses. J Control Release 172: 305-321. [CrossRef]

- Venters C, Graham W, Cassidy W (2004). Recombivax-HB: perspectives past, present and future. Expert Rev Vaccines 3: 119-129. [CrossRef]

- Wei M, Zhang X, Yu H, Tang ZM, Wang K, Li Z, Zheng Z, Li S, Zhang J, Xia N, Zhao Q (2014). Bacteria expressed hepatitis E virus capsid proteins maintain virionlike epitopes. Vaccine 32: 2859-2865. [CrossRef]

- West DJ, Calandra GB (1996). Vaccine induced immunologic memory for hepatitis B surface antigen: Implications for policy on booster vaccination. Vaccine 14: 1019-1027. [CrossRef]

- Yildiz I, Shukla S, Steinmetz NF, (2011). Applications of viral nanoparticles in medicine. Curr Opi Biotechnol 22: 901-908. [CrossRef]

- $\quad$ Zeng Q, Wen H, Wen Q, Chen X, Wang Y, Xuan W, Liang J, Wan S (2013). Cucumber mosaic virus as drug delivery vehicle for doxorubicin. Biomater 34: 4632-4642. [CrossRef]

- Zhao Q, Li S, Yu H, Xia N, Modis Y (2013). Virus-like particle-based human vaccines: quality assessment based on structural and functional properties. Trends Biotechnol 31: 654-63. [CrossRef]
Zhao L, Setha A, Wibowo N, Zhao CX, Mitter N, Yu C, Middelberg A (2014). Nanoparticle vaccines. Vaccine 32: 327- 337. [CrossRef]

Zhao Q, Potter CS, Carragher B, Lander G, Sworen J, Towne V, Abraham D, Duncan P, Washabaugh MW, Sitrin RD (2014). Characterization of virus-like particles in GARDASIL ${ }^{\oplus}$ by cryo transmission electron microscopy. Hum Vaccines \& Immunother 10: 734-739. [CrossRef]

- $\quad$ Zhou Z, Bedwell GJ, Li R, Prevelige PE, Gupta JA (2014). Formation mechanism of chalcogenide nanocrystals confined inside genetically engineered virus-like particles. Sci Rep 4: 3832. [CrossRef]

- Zochowska M, Paca A, Schoehn G, Andrieu JP, Chroboczek J, Dublet B, Szolajska E (2009). Adenovirus dodecahedron, as a drug delivery vector. PLoS One 4: e5569. [CrossRef]

zur Hausen, H, (2001). Viruses in human cancers. Curr Sci 81 : 523-527.

- (2015) ABX203 (HeberNasvac) granted cuban marketing authorization to treat chronic Hepatitis B. Available at: http://www. abivax.com/images/pdf/ 151208_ABX203_Cuban_Authorization.pdf Accessed 29.03.2017. 